\title{
Impact Evaluation of Microcredit on Welfare of the Vietnamese Rural Households
}

\author{
Pham Bao Duong ${ }^{1} \&$ Pham Tien Thanh ${ }^{2}$ \\ ${ }^{1}$ Vietnam National University of Agriculture (VNUA), Hanoi, Vietnam \\ ${ }^{2}$ Ton Duc Thang University, Hochiminh City, Vietnam \\ Correspondence: Pham Tien Thanh, Ton Duc Thang University, Room B101, No. 19, Nguyen Huu Tho, Tan \\ Phong, District 7, Hochiminh City, Vietnam. Tel: 84-982-536-185. E-mail: phamtienthanh@tdt.edu.vn; \\ thanhpham1.6.85@gmail.com
}

Received: August 30, 2014 Accepted: September 30, 2014 Online Published: December 20, 2014

doi:10.5539/ass.v11n2p190 URL: http://dx.doi.org/10.5539/ass.v11n2p190

\begin{abstract}
This study evaluates the impact of microcredit on the welfare of the rural households in Vietnam, especially the poor, and investigates the determinants on the accessibility to microcredit programs. Propensity score matching (PSM) method and difference in difference (DID) method are employed to evaluate the impact. The results show that microcredit improves living standard of the rural households via increasing their income and consumption. However, for case of the rural poor, microcredit is found to only improve their consumption but there is no evidence about its impact on their income. This study also found that microcredit programs may not serve the poor households. Such indicators as age, education level, leadership status of household head, household size, dependency ratio, house value, geographic location, facilities of communes are proved to affect the probability of participating in microcredit programs.
\end{abstract}

Keywords: impact evaluation, microcredit, microcredit accessibility, Vietnam

\section{Introduction}

Vietnam is considered one of the few countries that have obtained the remarkable achievement in poverty reduction. As annual reports by General Statistics Office of Vietnam (GSO) showed, the poverty rate has declined from 37.4 percent in 1998 , to 18.1 percent in 2004 and to 13.4 percent in 2008. In a report by GSO (2008), the poverty rate in rural areas (16.1 percent) was higher than that in urban areas (6.7 percent). A large number of farmers in Vietnam still live in poverty and under poor living standards. Moreover, the rural households, especially the rural poor, the households without collaterals and households living in far-off or mountainous regions, have less accessibility to credit program. They face difficulties with accessing to credit sources especially, formal credit sources (Vietnam Bank for Social Policies [VBSP], the Vietnam Bank for Agriculture and Rural Development (VBARD), etc.,) as well as semi-formal sources (Women's Union Farmers' Association, or The People's Credit Funds, etc.,). As a result, they mostly borrow from informal sources (Friends and neighbors, Rotating savings, Pawnbrokers, etc.) for financing their production as well as for consumption. That results in the fact that they may fall into deeper debt and default debt. Therefore, in order to gain the more preeminent achievement of hunger eradication and poverty reduction as well as to help the poor escape from poverty, the Vietnamese Government have invested a great number of capitals as well as provided formal financial services to support the rural households, especially, the poor in rural areas via credit programs. One of the special credit programs that the Government applied is microcredit. Microcredit program is the one which provides small loans to poor people so that they can generate income to improve their living standard (Microcredit Summit, 1997). Typically, microcredit is granted to the poor households so that they can run production or do self-employment to generate income.

Many countries have applied microcredit programs as a tool of poverty reduction as well as a channel of providing credit to rural households. Microcredit has been popularly applied and its impact on welfare or living standard of households has been studied by many authors. However, there are mixed opinions about the impact of microcredit. Pitt \& Khandker (1998), Yunus (2009) considered microcredit is as a tool for the purpose of poverty alleviation and hunger eradication. Zaman (1999), Li, Gan and Hu (2010), You and Annim (2014), Adjei, Arun and Hossain (2009) affirmed that microcredit has positive impact on the household's welfare via increasing 
their income, consumption, schooling years, health condition. On the other side, some researchers argued that there is no significant impact of microcredit on welfare of households. Kazushi, Takayuki and Kazunari (2010) stated that there is no evidence of the microcredit program impact on the living standard which is reflected via assets and income, self-employment profit.

In Vietnam, there have been also some studies concerning the impact of microcredit program on the households, especially the households in rural areas and the poor rural households. Nguyen (2008), Pham and Lensink (2011), Nadine and Peter (2012) proved that microcredit programs have positive impact on welfare via increasing the incomes and expenditures, improving the quality of water supply and the sanity system as well as reducing poverty rate.

The general objective of this study is to assess the impact of the programs on the welfare of the households living in the rural areas, especially the poor. In order to achieve this overall goal, this study must meet the following specific objectives: (1) Evaluating whether microcredit programs improve the living standards of the household living in the rural areas; (2) Investigating whether microcredit programs truly serve the poor rural households; (3) Identifying the determinants of the rural households' participation in the microcredit programs.

Unlike the previous studies, this study employs two impact evaluation methods including Propensity Score Matching (PSM) and Difference in Difference (DID) for measuring the impact in order to capture the best conclusions. The analysis of this study relies on data collected by GSO, namely the Vietnam household living standard survey (VHLSS) in the year 2006 and 2008. The micro-loans in this study are only derived from formal sources granted by VBSP, which is considered as the greatest providers of microcredit and the most typical representative of financial institution of the Government in anti-poverty program. In Vietnam, majority of the poor households are living in the rural areas; therefore, this study mainly focuses on analyzing households in rural areas, especially, the poor rural households. In addition to present the impact of microcredit on welfare or living standard of the households, this study also presents the determinants of accessibility to microcredit programs of households living in the rural areas as well as the targeting issue of this program.

\section{Literature Review}

\subsection{Operation of Microcredit Program in Vietnam}

In Vietnam, microcredit program was first applied by Tinh Thuong (TYM) fund in 1992. TYM was established in 1992 based on the model of Grameen Bank of Bangladesh and managed by the Vietnam Women's Union. After that, some more Microfinance Institutions (MFIs) were established such as Binh Minh Community Development Consulting Company, Capital Aid Fund for Employment of the Poor (CEP), etc. However, at that time, the operation of microcredit programs by TYM as well as most of MFIs was not adjusted and controlled under a legal framework. Most of MFIs then were only considered as political social organization. Without legal framework, the MFIs had difficulty in mobilizing capital. After the promulgation of the decree 28/2005/ND-CP that prescribes the establishment of small-sized financial institutions and the decree of 165/2007/ND-CP that amends and implements decree 28/2005/ND-CP, microcredit has been remarkably improved and increased in great quantity.

Currently in Vietnam, there are main microcredit providers such as VBSP, CEP, TYM and M7, in which VBSP is the greatest providers of such kind of lending service nowadays. Therefore, this study analyses the impact of microcredit programs provided by VBSP only. The reasons to focus on only the case of VBSP are: (1) VBSP is the major provider of credit for the rural households as well as the poor; (2) VBSP is the most typical financial institution that best represents the Government's efforts in hunger eradication and poverty reduction campaigns; (3) Nowadays, VBSP is the greatest provider of microcredit in Gross Loan Portfolio as well as the number of borrowers, and these numbers tend to increase more and more. (Table A1 showed the operation of microcredit program by VBSP from 2005 to 2011).

\subsection{Determinants of the Accessibility to Microcredit Programs}

Credit (including microcredit) transaction procedure consists of two stages. In the first stage (demand side), households who demand credit apply for a certain amount of loan from formal or informal sources (the lenders). In the second stage (supply side), the lenders choose who can be granted credit and how much the loan size is, based on eligibility of the households. In a study of accessibility to formal rural credit in Nicaragua, Vaessen (2001) found that accessibility to credit was affected by the characteristics of supply-side (behaviors of banks or financial institutions) and demand-side (behaviors of households). In the case of Vietnam, Pham and Izumida (2002) analyzed the accessibility to rural credit via focusing on the determinants of borrowing of households (demand-side) and the determinants of credit rationing by the formal lending institutions (supply-side). This 
study analyzes the determinants of accessibility to microcredit based on demand-side. The determinants in this study will be classified into three levels: (1) Individual level, (2) Household level; and (3) Commune level.

Such factors at individual level as gender, age, square term of age, education, marital status, official status are considered as important determinants of participating in microcredit programs (Khandker, 2005; Nguyen, 2007; Li et al., 2011; Banerjee et al., 2009; Phan, Gan, Nartea, \& Cohen, 2013). Characteristics at household level such as ethnic, dependency ratio, land size per capita, house value are also found to significantly impact on the accessibility to microcredit programs of rural households (Gropp, Scholz, \& White, 1997; Pham \& Izumida, 2002; Vaessen, 2001; Khandker, 2005; Nguyen, 2007). Participation in microcredit programs are also explained via factors at commune level, including distance to bank, geographic location, and facilities of the commune (Khandker, 1998; Sharma \& Zeller, 1999; Li et al., 2011; Jose \& Quy-Toan, 2011; Phan et al., 2013).

\subsection{Impact of Microcredit on Welfare of the Rural Households.}

Many empirical studies showed that microcredit plays a very significant role in improving welfare of the poor in rural area. Microcredit has significant impact on many aspects of living standards of rural households such as income, consumption, health, schooling, poverty reduction level, etc. Khandker (2005); Yasmine (2008), Li et al. (2011), Imai, Arun and Annim (2010) stated that microcredit has positive impact on living standard of the poor households via increasing their consumption, and improving their children's education, income and assets. In a research for the case of Bangladesh, Pitt, Khankder, Chowdhury and Millimet (2003) found that microcredit has impact on health status of borrowers' children, but the results are various by gender. That is, credit provided to women has positive effect on health status of their children, while credit granted to men has no impact. A study for the case of Burkina Faso by Hennink and McFarland (2013) also proved that microcredit has positive impact on health condition of women. In contrast, Karlan and Zinman (2010) stated that there is no evidence of the impact of microcredit program on the living standard. Using PSM-DID method for the case of Indonesia, Kazushi et al. (2010) concluded that there is no impact of microcredit on the improvement of such measures as income/profit, durable assets, livestock, schooling expenditure, medical expense, female clothing expenditure. Similarly, the study for the case of India using randomized controlled trial by Banerjee, Duflo, Glennerster, and Kinnan (2009) found no evidence of microcredit on households' welfare; specifically, participation in microcredit program does not affect health condition, accessibility to education and women empowerment.

In general, there are different arguments over pros and cons of microcredit that can be summarized as follows: (1) Pros: Microcredit is found to improve the households' welfare or living standards as well as fight against poverty. Moreover, microcredit contributes a new channel of providing credit services to population with low income, especially the poor. (2) Cons: Microcredit is not considered as a "one size fit all" program for the poor or low income households: (i) Microcredit may not be suitable for the nomads and people with illness; (ii) In some specific cases, other assistance programs should be taken into consideration to better support the households ( $\mathrm{Li}$ et al., 2011); (iii) the participating households may not benefit from the program due to the misusages, and then they may even get into deeper debt.

For the case of Vietnam, Nguyen (2008) proved that microcredit programs enhance the incomes and expenditures of the rural households. Also in his research, microcredit program is found to decrease the poverty-gap and poverty-severity indexes as well as contribute to poverty reduction of the participating households positively. However, he found that among the participating households, the proportion of the non-poor is higher than that of the poor. Pham and Lensink (2011) reconfirmed that participation in microcredit programs has positive effect on self-employment profits of rural households. Moreover, they found that participation in microcredit program results in the higher increase in income of the poorest households than that of the medium-income households in Vietnam rural regions, then this leads to the positive impact on poverty alleviation. In a research on the case of the Vietnam rural households by Nadine and Peter (2012), microcredit program was founded to improve the quality of water supply and the sanity system reflected via safer removal of human waste.

\section{Method}

\subsection{Model of Determinants on Probability of Borrowing from Microcredit Program}

In order to identify the groups for comparison, we conduct a model to forecast the determinants on the households' accessibility to micro credit programs, which can be later interpreted as the propensity score of each households. There are two common modeling methods to determine the credit accessibility: logistic regression models by Aghion and Morduch (2005); Coleman (2006); Li et al. (2011), and probit models by: Imai et al. (2010); Kazushi et al. (2009). According to Caliendo and Kopeinig (2005), the results from logistic and probit 
models are very similar. In this study, a probit model is conducted to estimate the probability of accessibility to microcredit program.

The following model was formulated and developed by Aghion and Morduch (2005), Coleman (2006):

$$
\operatorname{Pr}\left(\mathrm{Cr}_{\mathrm{i}}=1\right)=\beta_{0}+\beta_{1} \mathrm{I}_{\mathrm{i}}+\beta_{2} \mathrm{H}_{\mathrm{i}}+\beta_{3} \mathrm{~V}_{\mathrm{i}}
$$

Where $C r_{i}$ represents participation in microcredit program of households ( 1 if households participate in microcredit program; and 0 otherwise); $I_{i}, H_{i}$ and $V_{i}$ denote vectors of variables. $I_{i}$ are the vector of variables reflecting household head's characteristics such as gender (HGENDER), age (AGE), square term of age (AGE2), education (HEDU), marital status (HMAR), and official status (OST); $H_{i}$ represent characteristics of household level, including ethnic (ETHNIC), household size (HHSIZE), dependency ratio (DEPRATE), land size per capita (LPC), house value (HVAL); $V_{i}$ denote features of the communes such as distance to bank (DISTANCE), facilities of the commune (Whether the commune has radio broadcasting station (RBS), road for automobile to access commune (RO), post office (PO)), dummy variables for regions (GEOF1, GEOF2, GEOF3 \& GEO2). (see Table A2).

\subsection{Impact Evaluation of Using PSM and DID Method}

PSM method was developed by Rosenbaum and Rubin (1983), and then it is applied in many studies such as by Khandker (2010), Sascha and Andrea (2002). Based on the impact evaluation procedure used by these authors, the following steps should be conducted:

In the first step, a probit model of determinants on accessibility to microcredit program is conducted. Then, the participation equation is estimated using regression method for probit model. The equation is written as follows:

$$
\operatorname{Pr}\left(\mathrm{Cr}_{\mathrm{i}}=1\right)=\Phi\left(\beta_{0}+\beta_{1} \mathrm{Z}_{\mathrm{i}}+\varepsilon_{\mathrm{i}}\right)
$$

Where: $\mathrm{Cr}_{\mathrm{i}}$ denotes Indicator of participation in the credit program; and $\mathrm{Z}$ represents determinants on the accessibility to the program. The estimated probability of participation or propensity score of each observation (households) can be calculated from this equation.

In the second step, the common support region will be specified. That is, some observations may be dropped out because they have too high or two low propensity score. In this step, the balancing test is simultaneously conducted to check whether, in each block, the average probability of participation in the program (Propensity score) and mean of $Z$ are not different between treated units and control units. This testing process is conducted via dividing the observations into blocks based on the estimated propensity scores (Dehejia \& Wahba, 2002).

In the next step, each participant will be matched with one or some non-participants based on closet propensity score. Then, the difference in outcomes such as income and consumption between each participant and non-participant are compared. This difference reflects the impact of the microcredit program with respect to each participant, or individual gain. Various techquiques of matching can be employed to match these two groups such as Nearest-neighbor, Caliper or radius, Stratification or interval.

In the last step, mean value of all individual differences will be calculated to capture average value which reflects the program impact with respect to the participants. Average effect of Treatment for the Treated (ATT) can be estimated as follows:

$$
\mathrm{ATT}=\mathrm{E}\left(\mathrm{Y}_{1 \mathrm{i}}-\mathrm{Y}_{0 \mathrm{i}} \mid \mathrm{Cr}_{\mathrm{i}}=1\right)=\mathrm{E}\left(\mathrm{Y}_{1 \mathrm{i}} \mid \mathrm{Cr}_{\mathrm{i}}=1\right)-\mathrm{E}\left(\mathrm{Y}_{0 \mathrm{i}} \mid \mathrm{Cr}_{\mathrm{i}}=1\right)
$$

Where, $\mathrm{Y}_{1 \mathrm{i}}$ denotes Potential outcome of treatment units; $\mathrm{Y}_{0 \mathrm{i}}$ denotes potential outcome of control units.

The outcomes encounter the problem of standard errors to be estimated incorrectly. In order to overcome this problem, estimating standard errors with PSM via using of the Bootstrap should be employed (Khandker, 2010). This technique draws repeated samples form original sample, and then re-estimates the properties such as standard error and bias with each sample.

PSM has become a widely accepted practice in credit program and policy research. PSM is one of the best techniques to reduce the selection biases; however, there still exist some shortcomings: (1) PSM does not measure the difference in an outcome pre-post attendance in the program overtime; and (2) Hidden bias may still exist because PSM take into account the unobservable characteristics. Therefore, DID method is also employed to mitigate this problem of selection and improve the accuracy of estimated results (Lester, 1946; Khandker, 2010). The DID model to evaluate the impact of microcredit can be written as follows:

$$
\mathrm{Y}_{\mathrm{it}}=\beta_{0}+\beta_{1} \mathrm{~T}+\beta_{2} \mathrm{Cr}_{\mathrm{it}}+\beta_{3} \mathrm{~T}^{*} \mathrm{Cr}_{\mathrm{it}}+\varepsilon_{\mathrm{it}}
$$

Where, $\mathrm{Y}_{\mathrm{it}}$ is the income/consumption that reflects welfare of the household $\mathrm{i}$ at time $\mathrm{t} ; \mathrm{Cr}_{\mathrm{it}}$ represents for participating/treated households $\left(\mathrm{Cr}_{\mathrm{it}}=1\right)$ and nonparticipating/control $\left(\mathrm{Cr}_{\mathrm{it}}=0\right)$ households; $\mathrm{T}$ represents time 
period ( $\mathrm{T}=0$ is the pre-program period; $\mathrm{T}=1$ is the post-program period); and $\varepsilon_{i t}$ is the Error term. In DID method, treated group are household participating in the program at period $\mathrm{T}=1$ and not participating at period $\mathrm{T}=0$, while control group are households without participating in both periods. In order to capture the DID estimator correctly, the parallel trend/ common trend assumption needs to be satisfied. Instead of using DID with ordinary least squared, this study applied DID with fixed-effects regression.

DID method measure the difference in outcomes pre - post attendance in the program; the difference in outcomes among factors at the same time (Separate the impact of Microcredit and other factors on welfare); and the difference in outcome of impact of the program over time. DID method using panel data can control the unobserved and time-invariant variables. However, the drawback of DID Method is that it still does not measure the impact of loan size on welfare.

\subsection{Data Description}

\subsubsection{Survey Area}

Data is collected in a household standard living survey in Vietnam rural area in the year 2006 and 2008. The rural area in Vietnam has geographically diversified characteristics such as mountain, plain, sea, forest etc. People living in such areas are mostly involved in various production activities such as crop, fishery, livestock, etc. However the rural areas often suffer from natural disasters such as drought, flood, pestilent insects, etc. That causes damage to production activities in terms of affecting the production facilities such as irrigation systems, and then result in difficulties as well as disadvantages towards rural households whose means of living are mostly dependent on these production activities.

This study employed the dataset, named, "Vietnamese Household Living Standard Surveys" (VHLSS) collected by General Statistics Office (GSO) in 2006 and 2008. This data set provides information about households' characteristics, welfare as well as the attendance in various programs such as microcredit. VHLSS is conducted nation-wide, specifically there are 9,189 households for income and expenditure survey in 3,063 communes, from each of which three households are surveyed. VHLSS is designed to be representative for the whole country.

\subsubsection{Sample Selection}

For the case of impact evaluation using PSM, cross-sectional data for the year 2008 is employed. Based on the literature of PSM method, the comparison groups are specified as follows: (1) Treatment group includes the households who only participate in the microcredit program within the survey of 2008. (2) Control group includes the households who neither participate in the microcredit program nor the any other credit programs within the survey of 2008. From this criteria, 290 rural households are found to attend in microcredit program (Treated households) while there are 2096 nonparticipants (control households).

When applying DID to evaluate the impact, panel data for 2006 and 2008 is constructed. Based on the literature of DID method, the comparison groups are classify as follows: (1) Treatment group includes households who only participate in the microcredit program within the survey of 2008 and do not participate in any other credit program in 2006; and (2) Control Group includes the households who neither participate in the microcredit program nor the any other credit programs within the survey of both 2006 and 2008. Moreover, after matching the households in two waves, some control units are intentionally dropped out of the sample because they have some different characteristics with the treated households. The drop-out process relies on such geographical characteristics as geographical factors (Coastal/ Midland, plain, and mountainous area), geographical location (Not far-off and far-off region), village/communes, districts, etc. This process aims at reducing the difference in observed characteristics between treatment and control group as well as increasing the likelihood that these two groups follow the same trend. Based on the above procedure and criteria, 179 households are selected. Among these 179 households, 73 households participate in microcredit programs within the survey of 2008 and do not participate in any credit program in 2006 (treated households), and 106 households do not participate in any credit program in the survey both 2006 and 2008 (control households).

\section{Results and Discussion}

\subsection{Results on Accessibility to Microcredit Program}

The values of Percentage of Correctness Prediction (Count $R^{2}$ ) in both models indicate that the observed characteristics in the chosen model are well-specified. For the case of all rural households, it was concluded that Age (AGE) has positive relationship with probability of accessing to microcredit program (significant at $5 \%$ level), while square term of age (AGE2) has negative impact on microcredit program participation (at $1 \%$ level). Household heads with higher education level (HEDU) have greater tendency to borrow microcredit programs 
and this effect is significant at $5 \%$ level. Official status (OST) is positively related to microcredit program participation at $10 \%$ significant level. This conclusion is similar to the findings of Mpuga (2010); House value (HVAL) has negative impact on microcredit accessibility (significant at $1 \%$ level). Households in the mountainous (GEOF2) and far-off region (GEO2) have higher probability of microcredit participation and the impacts are highly significant at $1 \%$ and $5 \%$ level respectively. Households living in the communes with radio broadcasting station (RBS) have less probability of participation in microcredit programs at $5 \%$ significant level.

Table 1. Probity estimations of determinants on accessibility to microcredit program

\begin{tabular}{lllllll}
\hline \multirow{2}{*}{ Variable } & All Rural Household & & \multicolumn{3}{l}{ Poor Rural Household } \\
& Coef. & Z & Marginal Effect & Coef. & Z & Marginal Effect \\
\hline HGENDER & -0.166 & $(1.25)$ & -0.0306 & 0.262 & $(0.92)$ & 0.081 \\
AGE & 0.053 & $(2.51)^{* *}$ & 0.0091 & -0.028 & $(0.68)$ & -0.009 \\
AGE2 & -0.001 & $(3.16)^{* * *}$ & -0.0001 & 0.000 & $(0.24)$ & 0.000 \\
HEDU & 0.025 & $(2.22)^{* *}$ & 0.0044 & 0.087 & $(3.27)^{* * *}$ & 0.028 \\
HMAR & 0.070 & $(0.46)$ & 0.0118 & -0.093 & $(0.31)$ & -0.030 \\
OST & 0.239 & $(1.67)^{*}$ & 0.0474 & -0.033 & $(0.07)$ & -0.010 \\
ETHNIC & 0.148 & $(1.30)$ & 0.0243 & 0.522 & $(1.99)^{* *}$ & 0.153 \\
HHSIZE & 0.030 & $(1.16)$ & 0.0052 & 0.139 & $(2.24)^{* *}$ & 0.044 \\
DRATE & -0.052 & $(0.89)$ & -0.0090 & -0.298 & $(2.01)^{* *}$ & -0.095 \\
LPC & 0.001 & $(0.14)$ & 0.0001 & 0.003 & $(0.43)$ & 0.001 \\
HVAL & -0.002 & $(3.18)^{* * *}$ & 0.0004 & 0.004 & $(2.00)^{* *}$ & 0.001 \\
DISTANCE & 0.001 & $(0.31)$ & 0.0002 & 0.003 & $(0.37)$ & 0.001 \\
GEOF1 & -0.179 & $(1.50)$ & -0.0287 & -0.031 & $(0.12)$ & -0.010 \\
GEOF2 & -0.372 & $(3.71)^{* * *}$ & -0.0660 & -0.193 & $(0.84)$ & -0.061 \\
GEO2 & 0.232 & $(2.46)^{* *}$ & 0.0437 & 0.479 & $(2.15)^{* *}$ & 0.162 \\
RBS & -0.223 & $(2.47)^{* *}$ & -0.0422 & -0.269 & $(1.30)$ & -0.089 \\
RO & 0.012 & $(0.10)$ & 0.0020 & 0.403 & $(1.46)$ & 0.114 \\
PO & -0.097 & $(0.88)$ & -0.0177 & 0.535 & $(1.87)^{*}$ & 0.145 \\
CONSTANT & -1.857 & $(3.40)$ & & -1.739 & $(1.58)$ & \\
Pseudo R & 0.0848 & & & 0.159 & & \\
Count R ${ }^{2}(\%)$ & 87.85 & & & 75.29 & & \\
Obs & 2386 & & & 340 & & \\
\hline
\end{tabular}

Notes: *significant at $10 \%$ level, $* *$ significant at $5 \%$ level, $* * *$ significant at $1 \%$ level.

${ }^{\mathrm{a}}$ Absolute value of $\mathrm{z}$ statistics in parentheses.

For the case of the poor rural household, it may be concluded that Education of household head has positive relationship with accessibility to microcredit programs and this impact is statistically significant at $1 \%$ level; Households of main ethnic groups such as Kinh or Hoa have more probability of borrowing from microcredit sources (significant at 5\% level). Households with more member or higher house value are more likely to participate in the program at significant $5 \%$ level. Households with higher dependency ratio have more demand for microcredit loans at significant level of 5\%. A household living in the village in which there is a post office will have more likelihood of participating in microcredit program and this impact is statistically significant at $10 \%$ level.

This study also investigates whether microcredit program serve the poor or not. From Table 2, it was found that among 340 households eligible for microcredit program, there are only 99 households (or about 29.12 percent) who received the loan from VBSP. Therefore, it can be stated that microcredit programs by VBSP do not serve the poor households. To reconfirm this statement, Table 3 showed that among the participants, about 34.14 percent are eligible for microcredit programs, while the proportion of the ineligible is much higher at about 65.86 percent. From this result, it may conclude that majority of microcredit programs' clients are not the poor. 
Table 2. Credit access with respect to eligible households

\begin{tabular}{lll}
\hline & Eligibility (Poor household) & \\
& Frequency & Percentage \\
\hline Non-participants & 241 & $70.88 \%$ \\
Participants & 99 & $29.12 \%$ \\
Total & 340 & $100.00 \%$ \\
\hline
\end{tabular}

Source: Calculated from VHLSS Data 2008

Table 3. Distribution of eligibility with respect to treatment households

\begin{tabular}{lll}
\hline & \multicolumn{2}{l}{ Program Participation } \\
& Frequency & Percentage \\
\hline Ineligibility (Non-poor household) & 191 & $65.86 \%$ \\
Eligibility (Poor household) & 99 & $34.14 \%$ \\
Total & 290 & $100.00 \%$ \\
\hline
\end{tabular}

Source: Calculated from VHLSS Data 2008

\subsection{Results on Impact of Microcredit on Welfare of Rural Households}

From Table 4, it was proved that there is difference in income per capita and consumption per capita between control and treatment group at significant level of 1 percent. With respect to all households living in rural areas, the participating households are 74 thousand VND (equivalent 5.5 percent) higher in income per capita and 54 thousand VND (equivalent 7.3 percent) higher in consumption per capita than non-participating households. On the case of only poor households in rural areas, the income per capita of the participants is 55 thousand VND (or equivalent 8.6 percent) higher than that of non-participants, while the consumption per capita is 74 thousand VND (or equivalent 15 percent) higher.

Table 4. Impact of microcredit using independent sample T-test methods

\begin{tabular}{lllll}
\hline & \multicolumn{2}{l}{ All Rural Households } & \multicolumn{2}{c}{ Poor Rural Households } \\
& Impact & T-stat & Impact & T-stat \\
\hline Income per Capita (\%) & 5.5 & $2.59^{* * *}$ & 8.6 & $2.27^{* *}$ \\
Consumer per Capita (\%) & 7.3 & $3.46^{* * *}$ & 15.0 & $3.81^{* * *}$ \\
Income per Capita (1000VND) & 74 & $3.51^{* * *}$ & 55 & $2.61^{* * *}$ \\
Consumption per Capita (1000VND) & 54 & $3.64^{* * *}$ & 74 & $4.08^{* * *}$ \\
\hline
\end{tabular}

Note: *significant at $10 \%$ level, $* *$ significant at $5 \%$ level, $* * *$ significant at $1 \%$ level.

Source: Calculated from VHLSS Data 2008

Independent Sample T-test is considered as a normal method to compare the difference in average income/consumption between two groups. However, the result generate by this method is not as reasonable and accurate as that of PSM or DID method.

Table 5 shows that, the balancing property is satisfied. Regarding all rural households, the numbers of households falling into common support region are 2284 households, including 290 treatments and 1994 controls. For the case of the poor rural households, there are 330 households in common support region, consisting of 99 treated unit and 330 control units.

Table 6 showed that partipation in microcredit programs truly results in a higher increase in the average income per capita of rural households when using PSM. At the significance level of $5 \%$, the increase in the average income per capita of participating households is higher by 90.3 or 91.8 or 93.9 thousand VND (equivalently 8.2 percent or 9 percent or 9.2 percent) than that of nonparticipating households via using NN, Radius and Stratification techniques. According to the result in Table 6, it is also found that participation in microcredit programs makes a higher increase in the average consumption per capita of rural households at the signigicance level of $1 \%$. The average consumption per capita of the treatment households was found to increase higher by 
about 73.3 or 77.7 or 86.8 thousand VND (equivalently 11.8 percent or 12.4 percent or 13 percent) than that of control households via using various techniques of PSM.

Table 5. Common support and balance test

\begin{tabular}{lll}
\hline & All Rural Households & Poor Rural Households \\
\hline Balancing test & Satisfying & Satisfying \\
Common Support Region & {$[.012981, .47304715]$} & {$[.01778183, .90920033]$} \\
Inferior of block of pscore & 5 & 8 \\
Before match & 2386 & 340 \\
Control & 2096 & 241 \\
Treatment & 290 & 99 \\
After match & 2284 & 330 \\
Control & 1994 & 231 \\
Treatment & 290 & 99 \\
\hline
\end{tabular}

Source: Calculated from VHLSS Data 2008

Table 6. Results on the impact of microcredit program on welfare of the rural households

\begin{tabular}{|c|c|c|c|c|c|c|}
\hline & & \multicolumn{3}{|l|}{ Income Per Capita } & \multicolumn{2}{|c|}{ Consumption Per Capita } \\
\hline & & $\begin{array}{l}\text { Difference } \\
\text { Amount }\end{array}$ & $\begin{array}{l}\text { Difference } \\
\text { Percentage }\end{array}$ & in & $\begin{array}{l}\text { Difference } \\
\text { Amount }\end{array}$ & $\begin{array}{l}\text { Difference } \\
\text { Percentage }\end{array}$ \\
\hline \multirow[t]{2}{*}{ DID } & $\begin{array}{ll}\text { Fixed } & \text { Effect } \\
\text { Regression } & \end{array}$ & $61.0(0.93)^{\mathrm{a}}$ & $9.2(1.26)$ & & $115.0(2.18)^{* *}$ & $14.5(2.32)^{* *}$ \\
\hline & Nearest Neighbor & $90.3(4.151)^{* * *}$ & $8.2(2.785)^{* * *}$ & & $73.3(3.936)^{* * *}$ & $11.8(3.237)^{* * *}$ \\
\hline \multirow[t]{2}{*}{ PSM } & Radius Matching & $91.8(2.383)^{* *}$ & $9.0(2.071)^{* *}$ & & $86.8(2.902)^{* * *}$ & $13.0(3.200)^{* * *}$ \\
\hline & Stratification & $93.9(4.112)^{* * *}$ & $9.2(3.343) * * *$ & & $77.7(6.309)^{* * *}$ & $12.4(6.299) * * *$ \\
\hline
\end{tabular}

Note: $*$ significant at $10 \%$ level, ${ }^{* *}$ significant at $5 \%$ level, ${ }^{* * *}$ significant at $1 \%$ level

${ }^{a}$ Absolute value of $\mathrm{t}$ statistics in parentheses; 50 bootstrap replications are performed.

Source: Calculated from VHLSS Data 2006 and 2008

From Table 6, when using DID with fixed-effect, microcredit was proved to results in a higher increase in the average consumption per capita of the rural participants than that of the non-participants (significant at level of $5 \%$ ). The increase in the average consumption per capita is higher for the participating rural household by 115 thousand VND (equivalently 14.5 percent) than for the non-participating rural households. The impact of microcredit on consumption using DID with fixed effect technique is higher the result via PSM method. However, there was no evidence about the impact of microcredit on the average income per capita of the rural households. The reasons are: (1) the borrowing households would take a sufficient time to generate profit because they invested their loan in production. (2) The households might spend their loan for their most basic needs or urgent situations (i.e. medical treatment). (3) The households encountered the breakdown in production activities.

From Table 6, it was found that using both methods also generate the same conclusion that the participation in microcredit program truly have positive impact on the consumption per capita of the participating households at significance level of 5\%. Moreover, the results in percentage change showed that the impact is slightly different between the two methods. The result using PSM stated that microcredit participation raises the consumption per capita of participating households by the range from 11.8 percent to 13 percent on average in comparison with that of non-participants, while the impact using DID with fixed-effects regression is 14.5 percent. However, when using these two methods to take into account the impact of microcredit on income per capita, there are inconsistent results between these two methods. Result by PSM method implied that there is positive significant impact of microcredit on the income per capita of rural participating households, and this Average effect of Treatment for the Treated (ATT) ranges from 8.2 percent to 9.2 percent at significant level of 5\%. On the other hand, the result by DID with fixed-effects regression also showed that microcredit participation increases average income per capita of the participating households by 9.2 percent, which is similar to that by PSM, but 
this impact is statistically insignificant. Therefore, DID with fixed-effects regression failed to prove the significant impact of participation in microcredit program on the income per capita of the households in rural areas.

The study also investigates the impact of microcredit program on the welfare of the rural poor households via the application of various techniques of PSM methods. From Table 7, it was found that partipation in microcredit programme truly results in a higher increase in the average consumption per capita of the rural poor (significant at level of 5\%). According to three different techniques of PSM, the increase in the average consumption per capita is proved to be higher for the participants by 65.9 or 71.7 or 98.1 thousand VND (equivalently 12.9 percent or 14.1 percent or 19.9 percent) than for the non-participants.

Table 7. Results on the impact of microcredit program on welfare of the rural poor

\begin{tabular}{lllll}
\hline & Income Per Capita & & \multicolumn{3}{l}{ Consumption Per Capita } \\
& ATT $(1000$ VND) & ATT (\%) & ATT $(1000$ VND) & ATT (\%) \\
\hline Nearest Neighbor & $52.0(1.66)^{\mathrm{a}}$ & $8.2(1.53)$ & $66.0(2.422)^{* *}$ & $12.9(2.27)^{* *}$ \\
Radius Matching & $86.0(1.45)$ & $13.6(1.60)$ & $98.0(2.50)^{* *}$ & $19.9(2.52)^{* *}$ \\
Stratification & $47.0(1.50)$ & $7.9(1.39)$ & $72.0(3.50)^{* * *}$ & $14.1(2.75)^{* * *}$ \\
\hline
\end{tabular}

Note: *significant at $10 \%$ level, $* *$ significant at $5 \%$ level, $* * *$ significant at $1 \%$ level;

${ }^{a}$ Absolute value of $\mathrm{t}$ statistics in parentheses; 50 bootstrap replications are performed.

Source: Calculated from VHLSS Data 2008

Table 7 showed that the average income per capita of the poor treatment households is insignificantly higher than that of the poor control households. That result can be explained by these following reasons: (1) in this study, all of the borrowers used their loan for doing business or running production, thus it takes a certain time for them to generate income. (2) The poor households do not have experience in investment, which results in using capital inefficiently. (3) In spite of doing investment, the poor might prioritize most of the loan for consumption to cover their basic needs. (4)The poor might encounter unexpected problems such as natural disasters, risk in production or sick household members (Table 8).

Table 8. Reasons of unchanged or worse living condition

\begin{tabular}{lllllll}
\hline & \multicolumn{2}{l}{ First Reason } & \multicolumn{2}{c}{ Second Reason } & \multicolumn{2}{c}{ Third Reason } \\
& No. & Percentage & No. & Percentage & No. & Percentage \\
\hline Negligible Aid & 47 & 18.29 & 33 & 12.84 & 10 & 8.06 \\
Expenditure on sick people & 81 & 31.52 & 28 & 10.89 & 6 & 4.84 \\
Natural disasters or risk in production & 29 & 11.28 & 20 & 7.78 & 14 & 11.29 \\
Expenditure on a funeral & 6 & 2.33 & 9 & 3.5 & 2 & 1.61 \\
Others & 94 & 36.58 & 34 & 13.23 & 8 & 6.45 \\
\hline
\end{tabular}

\section{Conclusions}

\subsection{Conclusions and Policy Implication}

Using PSM methods, this study found that microcredit has impact on welfare via increasing income per capita per month and consumption per capita per month. It is consistent with many previous studies and research papers, but the impact of microcredit in this study is not great. Meanwhile, with the application of DID method with fixed-effects technique, it was found that microcredit program truly has positive impact on consumption of rural households, and the result of DID with fixed-effects technique is slightly higher than that of PSM. However, contrary to PSM, the impact of microcredit on income of the rural households using DID with fixed-effects is statistically insignificant. Therefore, the rural households should be provided with supports such as training in effective investments and experience on doing business and running production as well as on minimizing risks in rural production so that they can use the microcredit loan more effectively to improve their income better or generate income. 
When using PSM method to evaluate the impact of microcredit for the case of the rural poor, microcredit is found to improve their living standard via smoothing their consumption, but there has been no evidence about its impact on their income. Therefore, the poor rural households also need to be provided with training programs so that they will not misuse the microcredit loans. Moreover, before the poor can take advantage of microcredit loan, they should be provided with special supporting programs including health care, education, infrastructure, employment and small grants. Their life needs to be ensured with these basic needs so that they can concentrate in doing business or running production (Li et al., 2011).

This study also found some findings about the determinants on the accessibility to microcredit programs. For the case of all rural households, such factors as age, education level and official status of household head; house value; location of household; village's facility (with or without radio broadcasting station) are found to have effect on the accessibility to microcredit programs. For the case of the poor rural households, the determinants on participation in microcredit program include education of household head; household's ethnic; family size; house value; dependency ratio; villages' facility (with or without a post office).

This study also found that microcredit programs may not truly serve the poor. Therefore, in order to support the poor, it is suggested that the gap between the banks and the poor should be reduced, and loan procedure needed to be simplified.

\subsection{Limitations}

In this study, there is no information about motivation for borrowing of the rural households. The borrowers may need to improve their living standard as well as escape poverty, or they borrow just because they may have good relationship with the lenders. Meanwhile, the others do not have good relationship with banks or officials, so they may be afraid of taking loan. If this problem exists, the division into comparison groups will become non-randomized, and then the accuracy of impact assessment will reduce.

When applying DID with fixed-effect model using panel data, this study draws a two-wave survey. However, the analysis lack information of whether the participating households drop out of the program prematurely or not (i.e. they still follow up the program or not). This problem may result in the attrition bias, thus estimator may be less correct.

\section{References}

Adjei, J. K., Arun, T., \& Hossain, F. (2009). The role of microfinance in asset building and poverty reduction: The case of Sinapi Aba Trust of Ghana. Manchester: Brooks World Poverty Institute.

Aghion, B. A., \& Morduch, J. (2005). The economics of microfinance. Cambridge, Mass: MIT Press.

Banerjee, A. V., Duflo, E., Glennerster, R., \& Kinnan, C. (2009). The miracle of microfinance? Evidence from a randomized evaluation. Washington, DC: CGAP.

Caliendo, \& Kopeinig. (2005). Some Practical Guidance for the Implementation of Propensity Score Matching. IZA Discussion Paper, 1588.

Coleman, B. E. (2006). Microfinance in Northeast Thailand: Who Benefits and How Much? World Development, 34(9), 1612-1638. http://dx.doi.org/10.1016/j.worlddev.2006.01.006

Dehejia, R. H., \& Wahba, S. (2002). Propensity Score Matching Methods for Non-Experimental Causal Studies. The Review of Economics and Statistics, 84, 151-161. http://dx.doi.org/10.1162/003465302317331982

Duong, P. B., \& Yoichi, I. (2002). Rural Development Finance in Vietnam: A Micro econometric Analysis of Household Surveys. World Development, 30(2), 319-335. http://dx.doi.org/10.1016/S0305-750X(01) 00112-7

Gropp, R., Scholz, J. K., \& White, M. J. (1997). Personal bankruptcy and credit supply and demand. The Quarterly Journal of Economics, 112(1), 217-251. http://dx.doi.org/10.1162/003355397555172

Hennink, M., \& McFarland, D. A. (2013). A delicate web: Household changes in health behavior enabled by microcredit in Burkina Faso. Global Public Health, 8(2), 144-158. http://dx.doi.org/10.1080/17441692. 2012.762032

Imai, K., Arun, T., \& Annim, S. K. (2010). Microfinance and Household Poverty Reduction: New evidence from India. World Development, 38(12), 1760-1774. http://dx.doi.org/10.1016/j.worlddev.2010.04.006

Karlan, D., \& Zinman, J. (2010). Expanding credit access: Using randomized supply decisions to estimate the impacts. Review of Financial Studies, 23(1), 433-464. http://dx.doi.org/10.1093/rfs/hhp092

Khandker, S. R. (1998). Fighting poverty with microcredit: Experience in Bangladesh. Published for the World Bank (pp. xii + 228). Oxford University Press. 
Khandker, S. R. (2003). Microfinance and poverty-evidence using panel data from Bangladesh. No 2945, Policy Research Working Paper Series from the World Bank.

Khandker, S. R. (2005). Microfinance and Poverty: Evidence Using Panel Data from Bangladesh. The World Bank Economic Review, 19(22), 263-286. http://dx.doi.org/10.1093/wber/lhi008

Khandker, S. R. (2010). Handbook on Impact Evaluation-Quantitative Method and Practice. The World Bank, Development Economics.

Khoi, P. D., Gan, C., Nartea, G. V., \& Cohen, D. A. (2013). Formal and informal rural credit in the Mekong River Delta of Vietnam: Interaction and accessibility. Journal of Asian Economics, 26, 1-13. http://dx.doi. org/10.1016/j.asieco.2013.02.003

Lester, R. A. (1946). Shortcomings of Marginal Analysis for the Wage-Employment Problems. American Economic Review, 36, 63-82.

Li, X., Gan, C., \& Hu, B. (2011). Accessibility to microcredit by Chinese rural households. Journal of Asian Economics, 22(3), 235-246. http://dx.doi.org/10.1016/j.asieco.2011.01.004

Li, X., Gan, C., \& Hu, B. (2011). The welfare impact of microcredit on rural households in China. The Journal of Socio-Economics, 40(4), 404-411. http://dx.doi.org/10.1016/j.socec.2011.04.012

Mpuga, P. (2010). Constraints in access to and demand for rural credit: Evidence from Uganda. African Development Review, 22(1). http://dx.doi.org/10.1111/j.1467-8268.2009.00230.x

Nguyen, H. C. (2007). Determinants of Credit Participation and Its Impact on Household Consumption: Evidence from Rural Vietnam. Discussion Paper.

Nguyen, V. C. (2008). Is a governmental micro-credit program for the poor really pro-poor? Evidence from Vietnam. The Developing Economies, 46(2), 151-187. http://dx.doi.org/10.1111/j.1746-1049.2008.00061.x

Pedrosa, J., \& Do, Q. T. (2011). Geographic Distance and Credit Market Access in Niger. African Development Review, 23(3), 289-299. http://dx.doi.org/10.1111/j.1467-8268.2011.00287.x

Pitt, M. M., Khankder S. R., Chowdhury, O. H., \& Millimet, D. L. (2003). Credit programs for the poor and the health status of children in rural Bangladesh. International Economic Review, 44(1), 87-118. http://dx.doi.org/10.1111/1468-2354.t01-1-00063

Pitt, M., \& Khandker, S. R. (1998). The impact of group-based credit programs on poor households in Bangladesh: Does the gender of participants matter? Journal of Political Economy, 106, 958-997. http://dx.doi.org/10.1086/250037

Reis, N., \& Peter, P. M. (2012). Water Supply or 'Beautiful Latrines'? Microcredit for Rural Water Supply and Sanitation in the Mekong Delta, Vietnam. ASEAS-Austrian Journal of South-East Asian Studies, 5(1), 10-29.

Rosenbaum, P. R., \& Rubin, D. B. (1983). The Central Role of the Propensity Score in Observational Studies for Causal Effects. Biometrika, 70, 41-55. http://dx.doi.org/10.1093/biomet/70.1.41

Sascha, O. B., \& Ichino, A. (2002). Estimation of average treatment effects based on propensity scores. The Stata Journal, 4, 358-377.

Sharma, M., \& Zeller, M. (1999). Placement and outreach of group-based credit organizations: The cases of ASA, BRAC, and PROSHIKA in Bangladesh. World Development, 27(12), 2123-2136. http://dx.doi.org /10.1016/S0305-750X(99)00106-0

Takahashi, K., Higashikata, T., \& Tsukada, K. (2009). The Short-Term Poverty Impact of Small-Scale, Collateral-Free Microcredit in Indonesia: A Matching Estimator Approach. The Developing Economies, 48(1), 128-155. http://dx.doi.org/10.1111/j.1746-1049.2010.00101.x

Tra, P., \& Robert, L. (2011). The impact of microcredit on self-employment profits in Vietnam. Economics of Transition, 20(1), 73-111.

Vaessen, J. (2001). Accessibility of rural credit in Northern Nicaragua: The importance of networks of information \& recommendation. Savings \& Development, 25(1), 5-32.

Yasmine, F. N. (2008). Microcredit and the socio-economic wellbeing of women and their families in Cairo. The Journal of Socio-Economics, 37(2), 644-656. http://dx.doi.org/10.1016/j.socec.2007.10.008

Yinger, J. (1998). Evidence on Discrimination in Consumer Markets. Journal of Economic Perspectives, 12(2), 23-40. http://dx.doi.org/10.1257/jep.12.2.23

You, J., \& Annim, S. (2014). The Impact of Microcredit on Child Education: Quasi-experimental Evidence from Rural China. Journal of Development Studies, 50(7), 926-948. http://dx.doi.org/10.1080/00220388.2014. 903243 
Zaman, H. (1999). Assessing the poverty \& vulnerability impact of micro-credit in Bangladesh: A case study of BRAC. World Bank Policy Research Working Paper, No.2145. Washington, D. C.: The World Bank. http://dx.doi.org/10.1596/1813-9450-2145

\section{Appendix A}

Table A1. Microcredit programs by VBSP from 2006 to 2011

\begin{tabular}{lllllll}
\hline Indicators & 2006 & 2007 & 2008 & 2009 & 2010 & 2011 \\
\hline Offices & 665 & 665 & 610 & 677 & 681 & 677 \\
Personnel & 7155 & 7501 & 7809 & 8370 & 8800 & 8900 \\
Number of active borrowers & 4695986 & 5648140 & 6792978 & 7536960 & 8166287 & 8519497 \\
Gross Loan Portfolio (thousand & 1149164 & 2181692 & 3017866 & 3929036 & 4588944 & 4932544 \\
USD) & 245 & 386 & 444 & 521 & 562 & 579 \\
Average loan per borrower (USD) & 9 & 14 & 31 & 36 & 21 & \\
Cost per borrower (USD) & 956 & 753 & 870 & 900 & 928 & 957 \\
Borrowers per staff member & 6529 & 3402 & 3884 & 3326 & 2827 & 2850 \\
Borrowers per loan officer & 2829
\end{tabular}

Source: www.mixmarket.org

Table A2. Descriptions of variables in the analysis of the determinants on accessibility to microcredit programs

\begin{tabular}{ll}
\hline Independent Variables & Description \\
\hline HGENDER & Gender of household head (=0: female; =1: male \\
AGE & Age of household head (years) \\
AGE2 & Square Age of household head (years) \\
HEDU & Education level of the household head (Years of schooling) \\
HMAR & Marital Status of household head \\
& (=0: Single; Divorced/ Separated; Widowed; = 1: Married or living with partners) \\
OST & Official Status of household head in the commune \\
& (=0: Not having official status; = 1: Having official status) \\
ETHNIC & Ethnic of household (=0: Other ethnic; =1: Kinh or Hoa) \\
HHSIZE & Household Size (Number of members in the household) \\
DEPRATE & Dependency ratio (Ratio of non-working over working member) \\
LPC & Land per capita (1000 meter square) \\
HVAL & House value (million dong) \\
DISTANCE & Distance to credit institutions or banks (kilometers) \\
GEOF1 & Region (=1: Coastal or Midland; =0: other regions) \\
GEOF2 & Region (=1: Plain Region; =0: other regions) \\
GEOF3 & Region (=1: Mountainous Region; =0: other regions) \\
$\boldsymbol{G E O 2}$ & Geographic location (=1: Far-off region; =0 :Not far-off region) \\
$\boldsymbol{R B S}$ & Commune with/without Radio Broadcast Station \\
& (=0: Without RBS; =1: With RBS) \\
RO & Commune with/without Road for automobile to access commune \\
$\boldsymbol{P O}$ & (=0: Without RO; =1: With RO) \\
\hline
\end{tabular}

Note: Italic variables are dummies.

\section{Copyrights}

Copyright for this article is retained by the author(s), with first publication rights granted to the journal.

This is an open-access article distributed under the terms and conditions of the Creative Commons Attribution license (http://creativecommons.org/licenses/by/3.0/). 